\title{
Crédito ou exportações?
}

Luciano Nakabashi*

Marcelo Curado ${ }^{* *}$

Apesar das previsões de retração do PIB da economia brasileira de 1\%, em 2009, podemos dizer que a sua situação é relativamente boa quando comparado às demais economias desenvolvidas e em desenvolvimento.

Mesmo que a queda do PIB, em 2009, seja semelhante à de países desenvolvidos, isso é uma boa notícia visto a maior instabilidade histórica do crescimento da economia brasileira quando comparado ao crescimento daquele grupo. Em outras palavras, em momentos de crise internacional sempre fomos mais atingidos do que a média dos países desenvolvidos pelo simples fato de sermos uma economia em desenvolvimento. Este fato indica que a economia brasileira ainda não está madura e suas instituições ainda não são suficientemente fortes para manter um crescimento mais estável ao longo do tempo.

Uma comparação seria com as crises dos países asiáticos, em 1997, da Rússia, em 1998, e do próprio país, em 1999, que nos atingiram de forma severa. Isso aconteceu mesmo considerando que o Brasil não tinha nenhuma relação direta com os elementos que levaram às duas primeiras crises acima mencionadas. Adicionalmente, a crise cambial que afetou o país, em 1999, foi apenas uma decorrência das anteriores.

Um fator crucial para explicar nosso melhor desempenho atual em relação a presente crise, que é muita mais severa quando se compara às crises internacionais dos anos 90, é o bom desempenho das exportações a partir de 2004 de forma a gerar uma acumulação de reservas sem a utilização de poupança externa.

$\mathrm{Na}$ crise atual, a própria redução das exportações acabou gerando uma retração da economia brasileira, ainda mais quando levamos em consideração seus efeitos sobre as expectativas. Ou seja, os agentes que perceberam uma contração da demanda em alguns setores da economia brasileira deixaram de investir e consumir com receio de que também fossem atingidos por ela.

\footnotetext{
* Luciano Nakabashi é doutor em economia pelo CEDEPLAR/UFMG, professor do Departamento de Economia da Universidade Federal do Paraná e coordenador do Boletim de Economia \& Tecnologia. Endereço eletrônico: luciano.nakabashi@ufpr.br.

** Marcelo Curado é doutor em Economia pela UNICAMP e professor do Departamento de Economia da Universidade Federal do Paraná.
} 
Outro elemento que tem sido destacado por vários analistas econômicos como crucial para entender os impactos da crise internacional no desempenho da nossa economia é a retração do crédito internacional. De fato, os dados do Banco Central do Brasil mostram que ocorreu uma queda significativa do crédito doméstico com recursos externos. Este passou de US $\$ 46,7$ bilhões, em setembro de 2008, para US $\$ 38,3$ bilhões, em fevereiro de 2009.

Essa queda de mais de $20 \%$ do financiamento externo certamente teve impactos relevantes no fluxo de comércio externo brasileiro. No entanto, dados da mesma instituição mostram que o crédito total brasileiro como proporção do PIB passou do 38,3\% para 41,6\%, no mesmo período. Ou seja, essa variável não teve grande relevância na retração dos investimentos e consumo interno. $\mathrm{O}$ que as evidências mostram é que alguns agentes estão enfrentando dificuldade na obtenção de financiamento pela elevação do risco de inadimplência e não pela falta de crédito.

Assim, a crise internacional com a conseqüente queda das exportações e piora das expectativas dos agentes afetou o nível de incerteza, elevando o risco. Esse risco mais elevado restringiu o crédito total disponível para os agentes e não o oposto.

Podemos concluir, então, que os principais mecanismos de transmissão da crise internacional no desempenho da economia brasileira são: 1) a queda das exportações; e 2) a piora nas expectativas dos agentes. A boa notícia é que a economia mundial começa a apresentar alguns sinais de melhora que tendem a melhorar tanto às exportações quanto às expectativas dos agentes brasileiros. 